\title{
MEDIA PRESENTASI PREZI PADA MATA PELAJARAN AKUNTANSI UNTUK MENINGKATKAN MOTIVASI BELAJAR SISWA
}

\author{
Indri Juriana Saputri \\ Diana Tien Irafahmi \\ Sumadi \\ Universitas Negeri Malang \\ indri.juriana@gmail.com
}

\begin{abstract}
The purpose of this research is to develop prezi presentation media and to asses the effectivity of such media to increase students' motivation at SMA Laboratorium Malang. The research model used is a model of development of Borg and Gall (1983). Shortened stages include: (1) need assessment; (2) product development; (3) expert validation; (4) product revision I; (5) field trials; (6) product revision II; and (7) the final product. The results show that: (1) prezi presentation media is valid/ feasible to use, as evidenced by a score of assessment by media expert which is $96.84 \%$ (valid/ feasible to use); by accounting materials expert is $89.00 \%$ (valid/ feasible to use); by students is $89.53 \%$ (valid/ feasible to use); and by teacher is $86.89 \%$ (valid/ feasible to use); (2) in the field trials, the results of Paired Sample $T$-Test for student motivation obtained significance value $0,000<0,05$, therefore prezi presentation media can increase students motivation. Suggestions for the future research is to develop prezi presentation media to another accounting materials and in line with 2013 curriculum.
\end{abstract}

Keywords: Learning media, presentation media, prezi

Abstrak: Tujuan dari penelitian dan pengembangan ini adalah mengembangkan media presentasi prezi yang layak digunakan dalam proses pembelajaran dan mengetahui efektivitas media dalam meningkatkan motivasi belajar siswa kelas XI IPS SMA Laboratorium Malang. Model penelitian yang digunakan dalam penelitian dan pengembangan ini adalah model pengembangan Borg and Gall (1983). Tahapan yang digunakan meliputi: 1) analisis kebutuhan awal, 2) pengembangan produk, 3) validasi ahli, 4) revisi produk I, 5) uji coba lapangan, 6) revisi produk II, dan 7) produk akhir. Hasil penelitian menunjukkan bahwa media presentasi prezi pada mata pelajaran Akuntansi ini valid/ layak digunakan, terbukti dengan skor penilaian oleh ahli media sebesar $96,84 \%$ (valid/ layak digunakan); ahli materi sebesar 89,00\% (valid/ layak digunakan); skor uji coba pengguna siswa sebesar 89,53\% (valid/ layak digunakan); dan uji coba pengguna guru sebesar 86,89\% (valid/ layak digunakan). Pada uji coba lapangan, dari hasil pengolahan data Paired Sample T-Test untuk motivasi siswa diperoleh nilai signifikasi $0,000<0,05$ sehingga media presentasi prezi dapat meningkatkan motivasi belajar siswa. Saran yang diajukan untuk pengembangan berikutnya yaitu mengembangkan media presentasi prezi dengan materi lain dan menggunakan kurikulum 2013.

Kata Kunci: Media pembelajaran, media presentasi, prezi

Pembelajaran yang menyenangkan dapat diciptakan guru dengan menggunakan metode belajar dan penggunaan media pembelajaran yang tepat sebagai alat bantu pencapaian tujuan pembelajaran. Menurut Wulandari (2014:2) adanya perkembangan teknologi yang pesat di dunia pendidikan saat ini menyebabkan perkembangan media pembelajaran juga semakin 
bervariasi. Karena itu guru dituntut untuk menguasai teknologi yang berkembang agar dapat menciptakan pembelajaran yang lebih menarik atau untuk memanfaatkan media pembelajaran yang ada.

Menurut Hamalik dalam Arsyad (2011:23) pemanfaatan media dalam pembelajaran dapat membangkitkan keinginan dan minat baru, meningkatkan motivasi dan rangsangan belajar dan bahkan berpengaruh secara psikologis kepada siswa. Salah satu manfaat media pembelajaran di kelas adalah sebagai media presentasi. Banyak media presentasi yang dapat dipakai saat ini, presentasi dengan menggunakan media pembelajaran yang inovatif akan menciptakan kegiatan pembelajaran yang lebih efektif.

Salah satu media yang bisa menjadi alternatif yang inovatif adalah prezi. Menurut Rosadi (2012) prezi adalah salah satu perangkat lunak pembuatan slide presentasi secara online. Berbeda dengan power point, prezi memberikan ruang yang lebih bebas untuk menuangkan kreasi dalam pembuatan slide presentasi. Prezi memiliki tampilan seperti mind map, sehingga lebih memudahkan siswa untuk memahami materi yang disampaikan, dengan begitu semua komponen atau media yang digunakan dalam presentasi dapat dipadukan sesuai dengan konsep. keunggulan dari media pembelajaran prezi adalah adanya zoomable canvas, sehingga dapat memfokuskan slide ke setiap kalimat dengan pergerakan slide yang cukup dinamis dan variatif. Hal ini akan memudahkan siswa untuk memahami informasi yang disampaikan. Kemudahan prezi dalam menyisipkan gambar, foto, ataupun video kedalam slide juga menunjang kemudahan dalam menyusun slide presentasi yang diinginkan (Rosadi, 2012).

Berdasarkan hasil observasi yang dilakukan oleh peneliti di SMA Laboratorium UM Malang dapat dilihat bahwa siswa merasa kesulitan saat pembelajaran akuntansi. Media presentasi yang digunakan guru di kelas masih menggunakan media power point dengan tampilan yang sangat sederhana. Guru masih menggunakan metode konvensional saat menjelaskan materi pelajaran. Hasil wawancara yang dilakukan peneliti terhadap beberapa siswa kelas XI IPS di SMA Laboratorium menyatakan merasa kesulitan dan kurang berminat terhadap mata pelajaran akuntansi. Hasil observasi yang dilakukan peneliti menunjukkan bahwa fasilitas yang ada di dalam kelas sangat mendukung guru dalam meningkatkan kreativitasnya dalam menyampaikan materi. Terdapat LCD proyektor di dalam kelas, namun masih banyak guru yang tidak memanfaatkan fasilitas yang ada.

Berdasarkan pengamatan di atas maka diperlukan media pembelajaran yang inovatif dalam kegiatan pembelajaran akuntansi yang didukung oleh fasilitas di sekolah yang sesuai dengan tujuan pembelajaran. Tujuan dari penelitian pengembangan ini adalah 
mengembangkan media prezi sebagai media presentasi yang layak digunakan dalam proses pembelajaran mata pelajaran akuntansi dan mengetahui efektivitas media prezi dalam meningkatkan motivasi belajar siswa kelas XI IPS SMA Laboratorium UM Malang.

Penelitian terdahulu sejenis yang telah dilakukan antara lain, Bakrowi (2007) melakukan penelitian yang berjudul "Microsoft Office Power Point Sebagai Media Pembelajaran Materi Unsur, Senyawa, dan Campuran Berbasis STAD”. Dari penelitian tersebut di dapat hasil bahwa pengimplementasian Microsoft Office Power Point sebagai multimedia pada saat pelaksanaan pembelajaran dengan model STAD adalah memotivasi siswa dalam pembelajaran, siswa lebih aktif dan lebih memperhatikan penjelasan dari guru, siswa tidak merasa bosan saat pembelajaran berlangsung dan menyukai animasi-animasi yang ditampilkan dalam media power point. Penelitian yang dilakukan Utari, dkk (2014) dengan judul "Pengembangan Media Pembelajaran Fisika Online Prezi dalam Pokok Bahasan Alat Optik pada Siswa Kelas X IPA SMA Negeri 3 Purworejo Tahun Pelajaran 2013/2014" menyatakan bahwa media pembelajaran online prezi layak digunakan sebagai media presentasi dalam pembelajaran fisika di kelas.

Perbedaan penelitian yang akan dikembangkan dengan penelitian sebelumnya adalah produk yang dikembangkan berupa media presentasi berbasis prezi pada mata pelajaran akuntansi dengan materi siklus akuntansi perusahaan jasa untuk siswa kelas XI IPS dengan menambahkan video, animasi, dan gambar yang menarik. Media pembelajaran yang dikembangkan ini, dibuat secara interaktif agar siswa tidak bosan pada saat pembelajaran akuntansi berlangsung. Media ini berisikan materi, contoh soal dan latihan soal yang disajikan dengan tampilan yang menarik dan bahasa yang mudah dimengerti oleh siswa. Dengan adanya pengembangan media pembelajaran berbasis prezi yang lebih baik ini, dapat dijadikan referensi oleh guru mata pelajaran akuntansi untuk digunakan dalam penyampaian materi pelajaran di kelas.

Pengembangan media presentasi prezi ini mengaplikasikan dan mengadopsi teori belajar konstruktivistik yang diwujudkan dalam suatu produk media pembelajaran. Teori Konstruktivistik menyatakan bahwa pembelajaran semestinya bersifat generatif, yaitu tindakan menciptakan suatu makna dari apa yang dipelajari. Beda dengan aliran behavioristik yang memahami hakikat belajar sebagai kegiatan yang bersifat mekanistik antara stimulus respon, kontruktivistik lebih memahami belajar sebagai kegiatan manusia membangun atau menciptakan pengetahuan dengan memberi makna pada pengetahuannya sesuai dengan pengalamannya. Konstruktivistik sebenarnya bukan merupakan gagasan yang baru, apa yang 
dilalui dalam kehidupan selama ini merupakan himpunan dan pembinaan pengalaman. Ini menyebabkan seseorang mempunyai pengetahuan dan menjadi lebih dinamis (Kartika, 2011:9). Menurut Windschitl dalam Supardan (2004:3), perkembangan konstruktivistik memang banyak digunakan dalam pendekatan-pendekatan pembelajaran. Konstruktivistik pada dasarnya adalah suatu pandangan yang didasarkan pada aktivitas siswa untuk menciptakan, menginterpretasikan, dan mereorganisasikan pengetahuan dengan jalan individual. Menurut pendekatan konstruktivistik, belajar merupakan suatu proses pembentukan pengetahuan. Pembentukan ini harus dilakukan oleh siswa. Siswa harus aktif melakukan kegiatan, aktif berfikir, menyusun konsep dan memberi makna tentang hal-hal yang sedang dipelajari. Guru dapat dan harus mengambil prakarsa untuk menata lingkungan yang memberi peluang optimal bagi terjadinya pembelajaran. Namun, yang akhirnya paling menentukan terwujudnya gejala belajar adalah niat belajar siswa sendiri. Dengan istilah lain, dapat dikatakan bahwa hakikatnya kendali belajar sepenuhnya ada pada siswa (Budiningsih, 2012:56).

Tujuan kontrukstivistik menurut Thobroni dan Mustofa (2011:108) adalah (a) mengembangkan kemampuan siswa untuk mengajukan pertanyaan dan mencari sendiri pertanyaan, (b) membantu siswa untuk mengembangkan pengertian dan pemahaman konsep secara lengkap, (c) mengembangkan kemampuan siswa untuk menjadi pemikir yang mandiri. Lebih menekankan pada proses belajar dan bagaimana belajar itu. Konstruktivistik sebagai deskripsi kognitif manusia sering diasosiasikan dengan pendekatan pedagogi yang mempromosikan learning by doing. Dengan demikian menurut teori ini, pembentukan pengetahuan terjadi sebagai hasil konstruksi manusia atas realitas yang dihadapinya.

Media presentasi prezi ini dapat dimanfaatkan oleh siswa dalam menyusun pengetahuan yang ingin diperoleh siswa tersebut mengenai materi laporan keuangan perusahaan jasa. Substansi dari media presentasi prezi ini adalah mempermudah siswa dalam memahami dan menunjang sumber belajar. Adanya pemanfaatan media yang praktis dan inovatif yang dikemas dalam media yang menarik dapat membangun mental siswa dalam membangun struktur pengetahuannya berdasarkan kematangan kognitif yang dimilikinya. Sementara dalam tujuan pembelajaran konstruktivistik juga ditegaskan bahwa siswa dapat mengembangkan kemampuan siswa yang sudah didapat dan menjadi pemikir yang mandiri dengan menekankan pada proses belajar itu sendiri, yang mana fungsi media juga memberikan kontribusi sebagai alat untuk mempermudah siswa dalam memahami suatu informasi. 
Mind Mapping (Peta Pikiran) dapat diartikan sebagai suatu cara untuk mengorganisasikan dan menyajikan konsep, ide, tugas atau informasi lainnya dalam bentuk diagram radial-hierarkis non-linier. Mind Mapping pada umumnya menyajikan informasi yang terhubung dengan topik sentral, dalam bentuk kata kunci, gambar (simbol), dan warna sehingga suatu informasi dapat dipelajari dan diingat secara cepat dan efisien. Tony Buzan, seorang berkebangsaan London telah menciptakan teori Mind Mapping. Tony Buzan adalah seorang penulis buku yang bertemakan human brain, kreatifitas dan pembelajaran dalam otak manusia dalam berfikir. Buzan mempelajari bahwa sebenarnya otak manusia jutaan kali lebih canggih dari komputer. Strategi Mind Mapping juga dapat menghilangkan kebosanan dalam mencatat secara tradisional, sehingga dalam hal ini otak akan lebih cepat mencerna serta mengingat catatan yang telah dibuat (Kurniawan, 2012).

Menurut Buzan (2006:5) Mind map adalah sebuah sistem berpikir yang bekerja sesuai dengan cara kerja alami otak manusia dan mampu membuka dan memanfaatkan seluruh potensi dan kapasitas otak manusia sehingga menjamin tingkat kreativitas dan kemampuan berpikir yang lebih tinggi bagi penggunaannya. Mind mapping juga merupakan rute yang hebat bagi ingatan, memungkinkan pembaca menyusun fakta dan pikiran sedemikian rupa sehingga cara kerja alami otak dapat dilibatkan sejak awal. Mengingat informasi akan lebih mudah dan lebih bisa diandalkan daripada menggunakan teknik mencatat tradisional. Mind mapping digambarkan dengan menggunakan garis lengkung, simbol, kata, dan gambar sederhana, mendasar dan alami sesuai dengan cara kerja otak. Dengan mind mapping maka akan tercipta pandangan yang menyeluruh terhadap pokok permasalahan. Memungkinkan pembaca merencanakan rute atau membuat pilihan dan mengetahui ke mana akan pergi. Mengumpulkan sejumlah besar data di suatu tempat. Mendorong pemecahan masalah dengan membiarkan pembaca melihat jalan-jalan terobosan yang kreatif.

Menurut Windura (2008) saat seseorang menggunakan mind map, berarti saat itulah seseorang sedang mengeluarkan seluruh kemampuan terbaik otaknya. Dengan demikian, penggunaan mind map akan menjamin tingkat kreativitas tertinggi dan akan menghasilkan kualitas terbaik dalam suatu pekerjaan. Mind mapping dapat membantu siswa dan guru dalam proses pembelajaran di kelas dengan meringkas bahan yang demikian banyak menjadi beberapa lembar saja yang jauh lebih mudah dapat dipelajari dan diingat oleh siswa. Dengan mind mapping, seluruh informasi-informasi penting dari setiap bahan pelajaran dapat diorganisir dengan menggunakan struktur yang sesuai dengan mekanisme kerja alami dari otak sehingga lebih mudah untuk dipahami dan diingat. 
Dalam bidang pendidikan, mind map mempunyai kegunaan yang sangat besar, terutama untuk belajar dan mengajar. Untuk keperluan belajar, mind map sangat bermanfaat pada saat meringkas, mencatat dan mengkaji ulang. Untuk keperluan mengajar, mind map sangat bagus diterapkan pada saat guru mencatat, mempersiapkan materi pengajaran dan managemen waktu pengajaran. Penggunaan mind map untuk keperluan belajar dan mengajar akan sangat membantu proses belajar dan mengajar itu sendiri (Silaban, 2012:4).

Dalam dunia pembelajaran, mind map mempunyai beberapa keunggulan yaitu: (1) Ide permasalahan didefenisikan dengan sangat jelas; (2) Pada saat bersamaan dapat melihat gambaran keseluruhan permasalahan (overview) sekaligus detail permasalahan (inview); (3) Ada hubungan antar informasi yang jelas sehingga setiap informasi terasosiasi satu dengan lainnya; (4) Unsur-unsur informasinya berupa kata kunci (keyword) yang sifatnya bebas dan fleksibel sehingga memungkinkan daya asosiasi kita berkembang secara terus menerus; dan (5) Unik sehingga mambantu memperkuat daya ingat. Mind Mapping dapat menjadi suatu alternatif di samping metode konvensional yang dapat meningkatkan efektifitas pembelajaran karena membantu mengorganisir informasi dengan baik. Dapat meningkatkan tingkat partisipasi siswa dalam belajar karena suasana belajar menjadi lebih menarik dan menyenangkan karena bahan pelajaran dapat diringkas ke dalam bentuk yang menarik serta mudah untuk dipahami dan diingat. Dapat membantu guru dalam menyampaikan materi pelajaran secara lebih efektif dan efisien (Yoga, 2007:13).

Media presentasi prezi merupakan salah satu media berbentuk mind mapping yang dapat digunakan guru dalam kegiatan belajar mengajar di dalam kelas. Mind mapping dalam media prezi lebih menekankan pada kata-kata kunci yang disusun berdasarkan pengelompokan informasi. Dalam media presentasi prezi, siswa dapat berimajinasi dan lebih kreatif karena dengan tampilan mind map, alur pikiran siswa lebih terarah, terdapat warnawarna yang membantu mempermudah siswa dalam mengingat serta memberi daya tarik sehingga mudah dipelajari, dapat dibuat disertakan gambar-gambar yang menunjang konsep atau ide sehingga lebih mudah dipahami siswa. Dengan tampilan mind map dalam media prezi dapat meningkatkan motivasi belajar siswa dan membantu guru dalam menyampaikan materi di depan kelas.

\section{METODE}

Pengembangan media presentasi prezi ini menggunakan model pengembangan Borg and Gall (1983) yang telah dimodifikasi sesuai dengan kebutuhan, dalam penelitian ini terdapat tujuh tahapan yaitu (1) analisis kebutuhan awal, (2) pengembangan produk (3) 
validasi ahli, (4) revisi produk I, (5) uji lapangan terbatas, (6) revisi produk II (7) produk akhir.

Media prezi yang telah dibuat perlu divalidasi dan di uji coba. Uji validitas media prezi dengan menggunakan validasi isi yang dilakukan oleh validator dengan mengisi angket guna memberikan penilaian terhadap produk yang telah dibuat. Data validasi ahli media diperoleh dari Dosen Teknologi Pendidikan di Fakultas Ilmu Pendidikan, sedangkan data validasi materi diperoleh dari guru mata pelajaran akuntansi di SMA Laboratorium Malang. Dalam pengembangan media presentasi ini menggunakan satu kali uji coba yaitu uji coba lapangan terbatas (pengguna guru dan siswa). Data uji coba pengguna guru diperoleh dari guru akuntansi di SMA Laboratorium Malang. Uji coba lapangan adalah 33 siswa kelas XI IPS 3 SMA Laboratoirum Malang.

Desain uji coba dalam pengembangan media presentasi prezi ini menggunakan prepost eksperimen, dengan memberikan angket motivasi belajar sebelum dan sesudah menggunakan media presentasi prezi. Pre-post eksperimen bertujuan untuk membandingkan motivasi belajar siswa sebelum menggunakan media prezi dengan sesudah menggunakan media prezi.

Instrumen pengumpulan data dilakukan dengan menggunakan angket. Angket merupakan instrumen pengumpulan data yang dilakukan dengan cara memberi seperangkat pertanyaan atau pernyataan tertulis kepada responden untuk dijawab (Sugiyono, 2009:199). Jenis angket yang digunakan yaitu angket tertutup. Sedangkan bagian angket tersebut pada lembar penelitian menggunakan skala likert. Skala likert digunakan untuk mengukur sikap, pendapat, dan persepsi seseorang atau sekelompok orang tentang fenomena sosial (Sugiyono, 2009:134).

Teknik analisis data validasi ahli dan uji coba pengguna menggunakan teknik analisis deskriptif persentase, yaitu cara yang digunakan untuk mengubah data kuantitatif menjadi bentuk persentase kemudian diinterprestasikan dalam bentuk kalimat yang bersifat kualitatif. Sedangkan analisis data untuk mengetahui efektifitas media prezi dengan menggunakan uji paired sample T-test. Adapun kriteria untuk menentukan kelayakan produk adalah sebagai berikut. 
Tabel 1 Kriteria Kelayakan Produk

\begin{tabular}{ll}
\multicolumn{1}{c}{ Persentase } & \multicolumn{1}{c}{ Keterangan } \\
\hline $80 \%-100 \%$ & Valid/ Layak \\
$60 \%-79 \%$ & Cukup Valid/ Cukup layak \\
$50 \%-59 \%$ & Kurang valid/ Kurang layak \\
$<50 \%$ & Tidak valid/ Tidak layak \\
\hline
\end{tabular}

Apabila hasil yang diperoleh dari validasi minimal telah mencapai 60\%-79\% maka media presentasi prezi sudah dapat dimanfaatkan sebagai media dalam kegiatan pembelajaran, karena pada presentase tersebut media sudah dikatakan cukup valid. Sebaliknya apabila hasil yang diperoleh kurang dari 60\%, maka media presentasi prezi dinilai kurang valid sehingga diperlukan revisi untuk memperbaiki agar layak digunakan dalam kegiatan pembelajaran.

\section{HASIL DAN PEMBAHASAN}

Pengembangan media prezi sebagai media presentasi akuntansi siswa kelas XI SMA pada pokok bahasan siklus perusahaan jasa dilakukan dengan beberapa tahapan. Tahapan pertama adalah analisis kebutuhan. Analisis kebutuhan dalam pengembangan ini dilakukan peneliti dengan observasi dan wawancara kepada guru mata pelajaran akuntansi dan beberapa siswa kelas XI IPS 3. Berdasarkan hasil observasi dan wawancara tersebut, peneliti mendapatkan temuan bahwa sekolah masih menggunakan kurikulum KTSP dalam kegiatan pembelajaran. Pokok bahasan laporan keuangan perusahaan jasa merupakan pokok bahasan yang akan disampaikan guru pada saat peneliti melaksanakan penelitian di SMA Laboratorium. Guru dalam penyampaian materi akuntansi masih menggunakan metode ceramah dan tidak menggunakan media dalam kegiatan pembelajaran. Metode ceramah tanpa penggunaan media yang digunakan guru di dalam kelas membuat siswa tidak aktif dan kurang berminat untuk mengikuti kegiatan belajar mengajar. Siswa kelas XI IPS cenderung lebih menyukai pembelajaran yang menarik dan menyenangkan daripada pembelajaran yang biasa digunakan guru di dalam kelas. Setelah dilakukan observasi dan wawancara terhadap guru akuntansi dan siswa di SMA Laboratorium Malang, maka pengembangan media presentasi prezi ini diharapkan dapat meningkatkan efektivitas dan kualitas pembelajaran dalam kegiatan pembelajaran akuntansi di kelas.

Tahap kedua adalah pengembangan produk, pengembangan produk terdiri dari perencanaan produk yang berisikan merumuskan butir-butir materi dilakukan dengan melihat pada silabus yang telah dibuat oleh SMA Laboratorium Malang. Peneliti juga mengumpulkan beberapa sumber yang relevan untuk mendukung materi yang akan dikembangkan dalam 
media presentasi prezi. Selanjutnya adalah tahap pembuatan produk, aplikasi untuk membuat media presentasi ini adalah aplikasi online prezi yang dapat diakses di www.prezi.com. Dalam pembuatan media presentasi prezi peneliti membagi beberapa tampilan antara lain: tampilan awal, tampilan materi, tampilan video pembelajaran, dan tampilan soal latihan.

\section{Tampilan Awal}

Tampilan pembukaan halaman awal media merupakan tampilan awal yang menunjukkan judul media dan tampilan umum keseluruhan dari materi yang akan disampaikan. Halaman ini bertujuan agar pengguna mengetahui materi yang akan disajikan dalam media presentasi prezi pada mata pelajaran akuntansi. Berikut beberapa tampilan awal pada media prezi untuk materi siklus akuntansi perusahaan jasa.
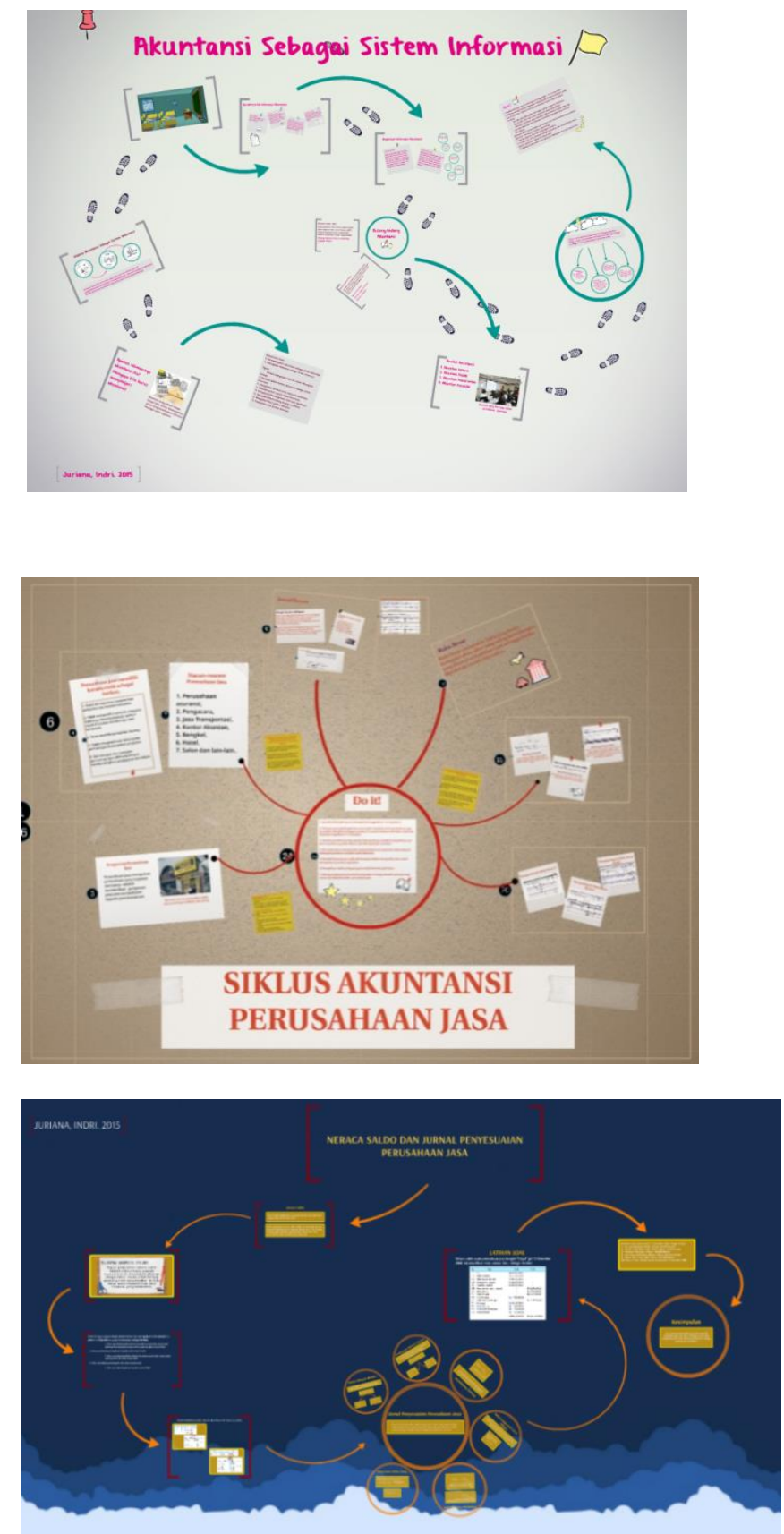


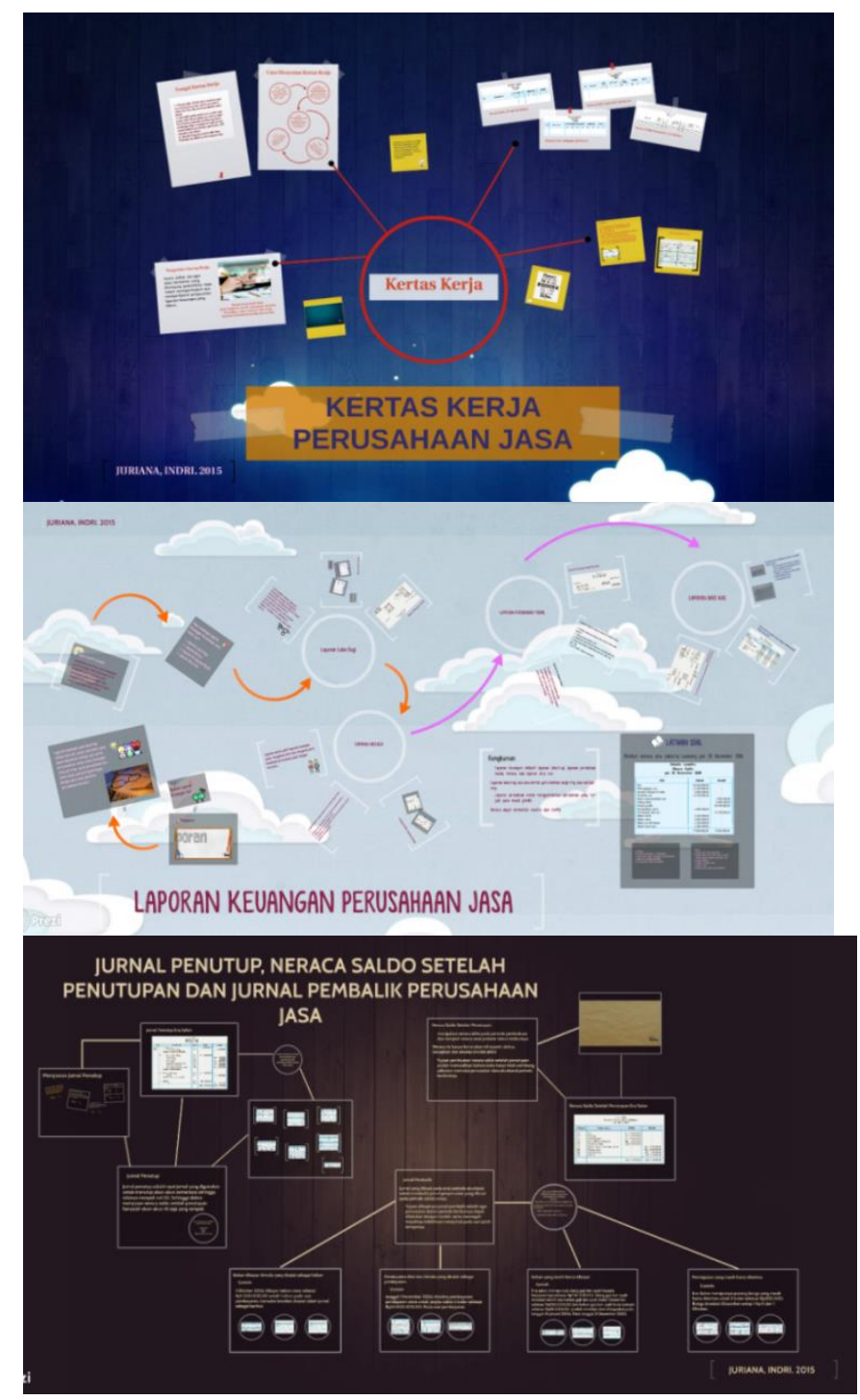

Materi siklus akuntansi perusahaan jasa dibagi menjadi 6 bagian. Materi 1 berisi mengenai materi akuntansi sebagai sistem informasi; materi 2 berisi pengertian perusahaan jasa, persamaan dasar akuntansi, jurnal umum dan buku besar; materi 3 berisi materi nerca saldo dan jurnal penyesuaian perusahaan jasa: kemudian materi 4 berisikan materi kertas kerja atau neraca lajur perusahaan jasa; materi 5 berisikan materi laporan keuangan perusahaan jasa dan yang terakhir pada materi 6 berisikan materi jurnal penutup, neraca saldo setelah penutupan dan jurnal pembalik.

Pada tampilan awal dalam media presentasi prezi ini, pengguna dapat melihat secara keseluruhan materi ajar yang akan disampaikan. Pada awal tampilan akan terlihat judul materi beserta dengan seluruh tampilan materi, kemudian jika pengguna ingin melanjutkan ke tampilan kompetensi dasar dan materi ajar, pengguna harus menekan tombol "next" yang ada dalam tampilan layar. 


\section{Tampilan Materi}

Pada halaman ini pengguna dapat membuka tampilan materi sesuai dengan langkahlangkah yang telah dibuat, dengan menekan tombol "next" maka tampilan materi akan keluar. Berikut salah satu tampilan materi dalam media prezi.

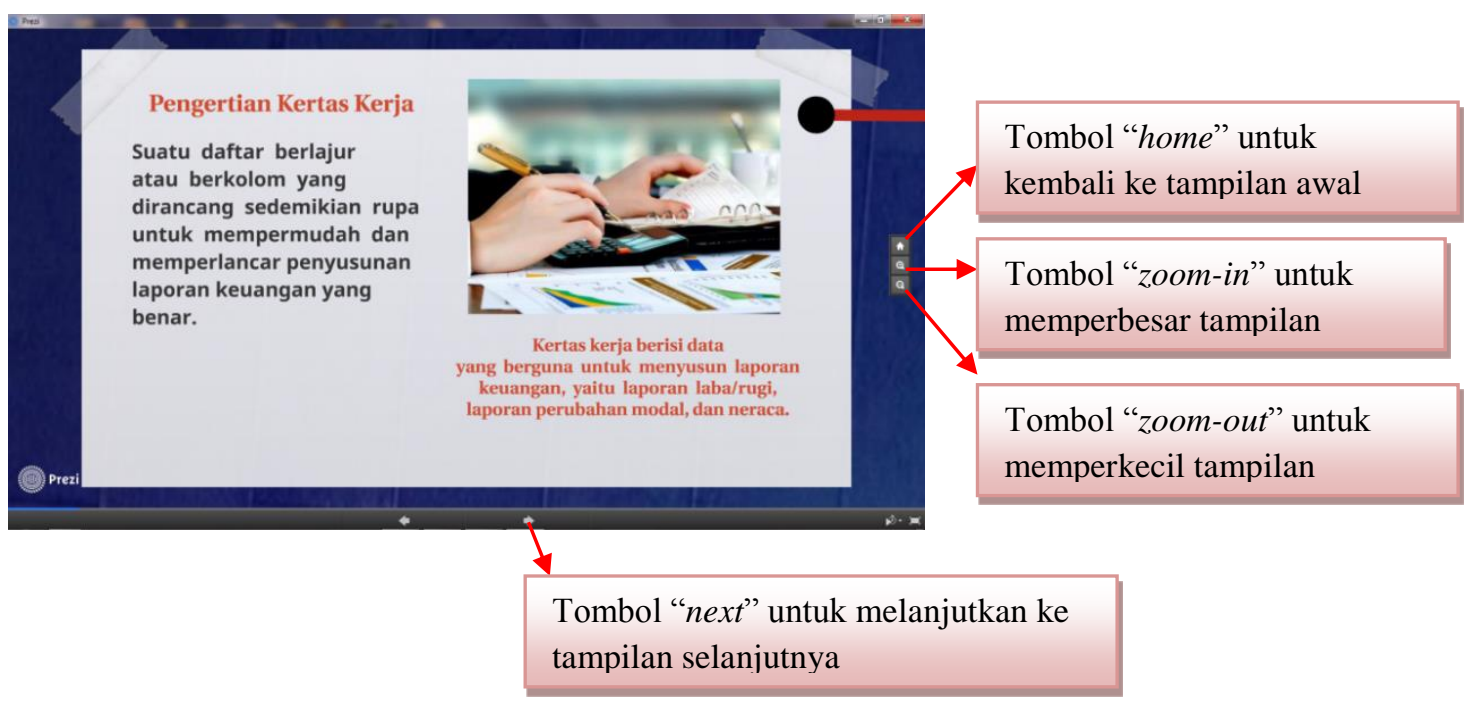

Pada media prezi yang dikembangkan, ditambahakan pula video pembelajaran. Video pembelajaran dapat mulai berjalan jika menekan tombol "play" pada tampilan. Penambahan video pembelajaran ini bertujuan agar proses pembelajaran di dalam kelas lebih menarik dan meningkatkan motivasi belajar siswa. Berikut tampilan video pembelajaran dalam media presentasi prezi.

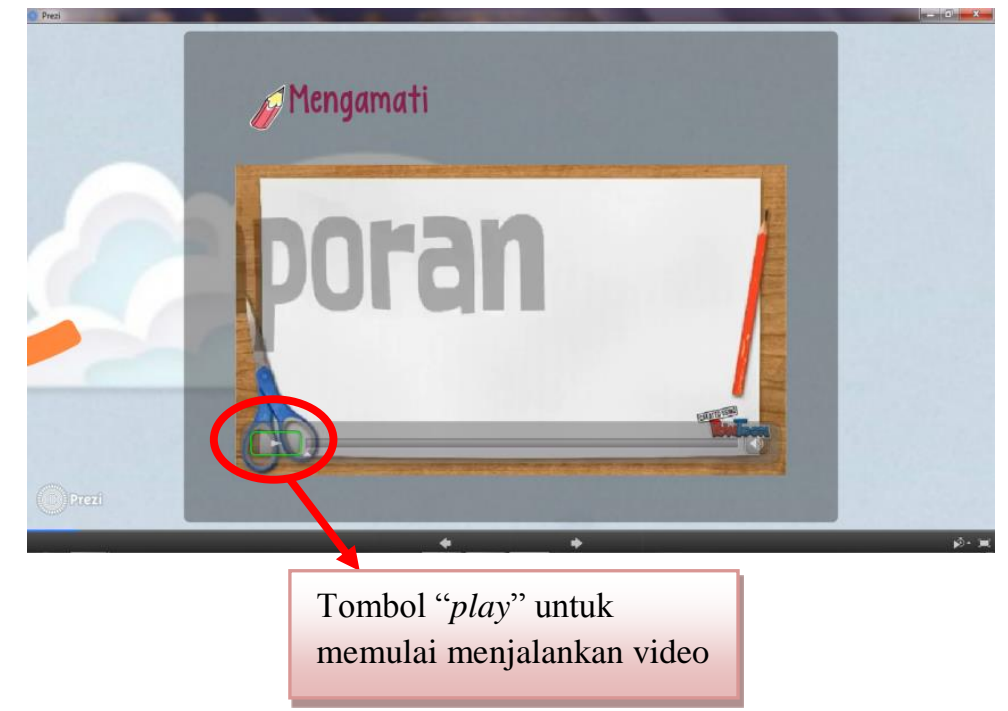




\section{Tampilan Soal Latihan}

Pada tampilan akhir media presentasi prezi diberikan soal latihan untuk siswa.

Tampilan latihan soal dibuat semenarik mungkin agar siswa termotivasi dalam mengerjakan soal. Berikut tampilan soal latihan yang ada dalam media prezi.

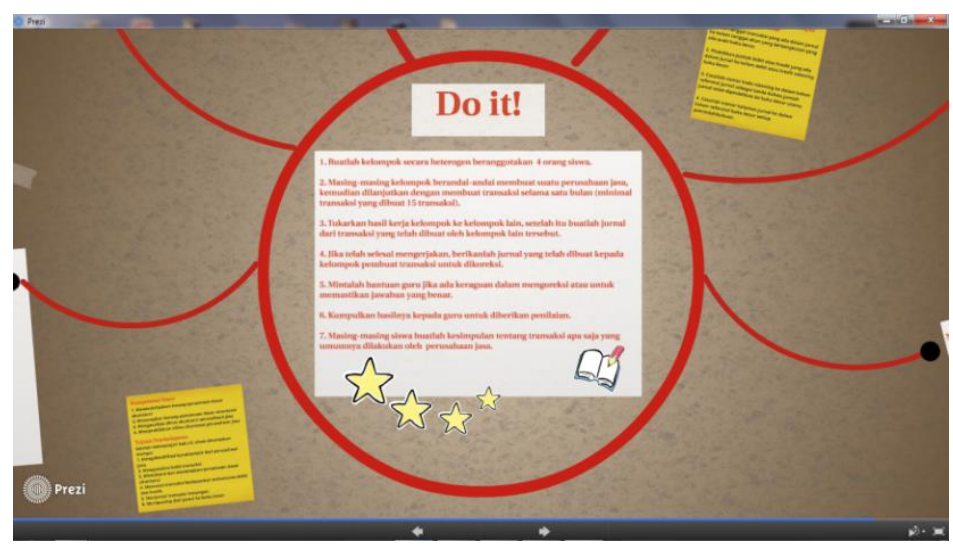

Langkah selanjutnya adalah uji validitas. Uji validitas melibatkan 2 validator yaitu validasi ahli media dan validasi ahli materi. Berikut ini data kuantitatif yang diperoleh dari hasil uji validasi media dan validasi materi.

Tabel 2. Data Kuantitatif Validasi Ahli Media

\begin{tabular}{lcc}
\hline \multicolumn{1}{c}{ Kompetensi } & persentase & Kriteria kevalidan \\
\hline Kualitas Teknis & $100 \%$ & Valid \\
Penyajian Materi & $93,33 \%$ & Valid \\
Keinteraktifan & $93,33 \%$ & Valid \\
Soal Latihan & $100 \%$ & Valid \\
Lain-lain & $100 \%$ & Valid \\
\hline \multicolumn{1}{c}{ Rata-rata } & $\mathbf{9 6 , 8 4 \%}$ & Valid/ dapat digunakan \\
\hline
\end{tabular}

Tabel 3. Data Kuantitatif Validasi Ahli Materi

\begin{tabular}{lcc}
\hline \multicolumn{1}{c}{ Kompetensi } & persentase & Kriteria kevalidan \\
\hline Penyajian Materi & $92 \%$ & Valid \\
Keinteraktifan & $90 \%$ & Valid \\
Balikan & $80 \%$ & Valid \\
Soal Latihan & $80 \%$ & Valid
\end{tabular}


Valid

\section{Rata-rata}

Berdasarkan hasil uji validasi ahli media dari tabel 2, memperoleh rata-rata sebesar 96,84\% dan dapat disimpulkan bahwa media presentasi prezi yang telah dikembangkan oelh peneliti valid dan laya digunakan dalam proses pembelajaran akuntansi. Hasil validasi materi memperoleh rata-rata persentase sebesar $89,00 \%$ dan dapat disimpulkan bahwa media presentasi prezi yang telah dikembangkan oleh peneliti valid dan layak digunakan dalam proses pembelajaran akuntansi.

Tahap berikutnya adalah uji coba pengguna siswa dan guru. Materi yang digunakan dalam uji coba pengguna adalah laporan keuangan perusahaan jasa. Uji coba pengguna dilakukan untuk mengetahui kelayakan dan kemenarikan produk yang dihasilkan berdasarkan prespektif pengguna guru dan siswa. Berikut ini data kuantitatif yang diperoleh dari uji coba pengguna siswa dan guru.

Tabel 4. Data Uji Coba Pengguna Siswa

\begin{tabular}{lcc}
\hline \multicolumn{1}{c}{ Kompetensi } & persentase & Kriteria kevalidan \\
\hline Kualitas Teknis & $92,10 \%$ & Valid \\
Penyajian Materi & $88,56 \%$ & Valid \\
Keinteraktifan & $84,80 \%$ & Valid \\
Balikan & $87,20 \%$ & Valid \\
Keektifan & $89,60 \%$ & Valid \\
Soal Latihan & $87,80 \%$ & Valid \\
Lain-lain & $89,83 \%$ & Valid \\
\hline \multicolumn{1}{c}{ Rata-rata } & $\mathbf{8 9 , 5 3 \%}$ & Valid \\
\hline
\end{tabular}

Tabel 5. Data Uji Coba Pengguna Guru

\begin{tabular}{lcc}
\hline \multicolumn{1}{c}{ Kompetensi } & persentase & Kriteria kevalidan \\
\hline Penyajian Materi & $90,00 \%$ & Valid \\
Keinteraktifan & $80,00 \%$ & Valid \\
Balikan & $80,00 \%$ & Valid \\
Keektifan & $87,10 \%$ & Valid \\
Lain-lain & $93,33 \%$ & Valid \\
\hline \multicolumn{1}{c}{ Rata-rata } & $\mathbf{8 6 , 8 9 \%}$ & Valid \\
\hline
\end{tabular}


Dari tabel 4 data hasil uji coba pengguna siswa dapat dilihat persentase tertinggi adalah aspek kualitas teknis sebesar $92,10 \%$ dan persentase terendah adalah aspek keinteraktifan sebesar $84,80 \%$, rata-rata yang diperoleh dari uji coba pengguna siswa adalah $89,53 \%$. Hasil data ujicoba pengguna guru pada tabel 5 diperoleh niali tertinggi adalah aspek lain-lain sebesar 93,33\%, nilai terendah pada aspek keinteraktifan dan balikan diperoleh sebesar $80 \%$ dan rata-rata dari uji coba pengguna guru diperoleh sebesar $86,89 \%$ sehingga dapat disimpulkan bahwa media presentasi prezi yang telah dikembangkan layak digunakan dalam proses pembelajaran akuntansi.

Data analisis angket motivasi belajar siswa menggunakan uji Paired Sample T-test karena data variabel yang satu saling berkaitan (dependent) setiap satu sampel dikenai dua perlakuan yaitu apakah ada perbedaan motivasi belajar siswa sebelum diberikan media presentasi prezi dengan setelah diberikan media presentasi prezi. Berikut adalah hasil data analisis angket motivasi belajar siswa menggunakan uji Paired Sample T-test dengan menggunakan SPSS versi 21.

Tabel 6. Hasil Data Uji Paired Sample T-test

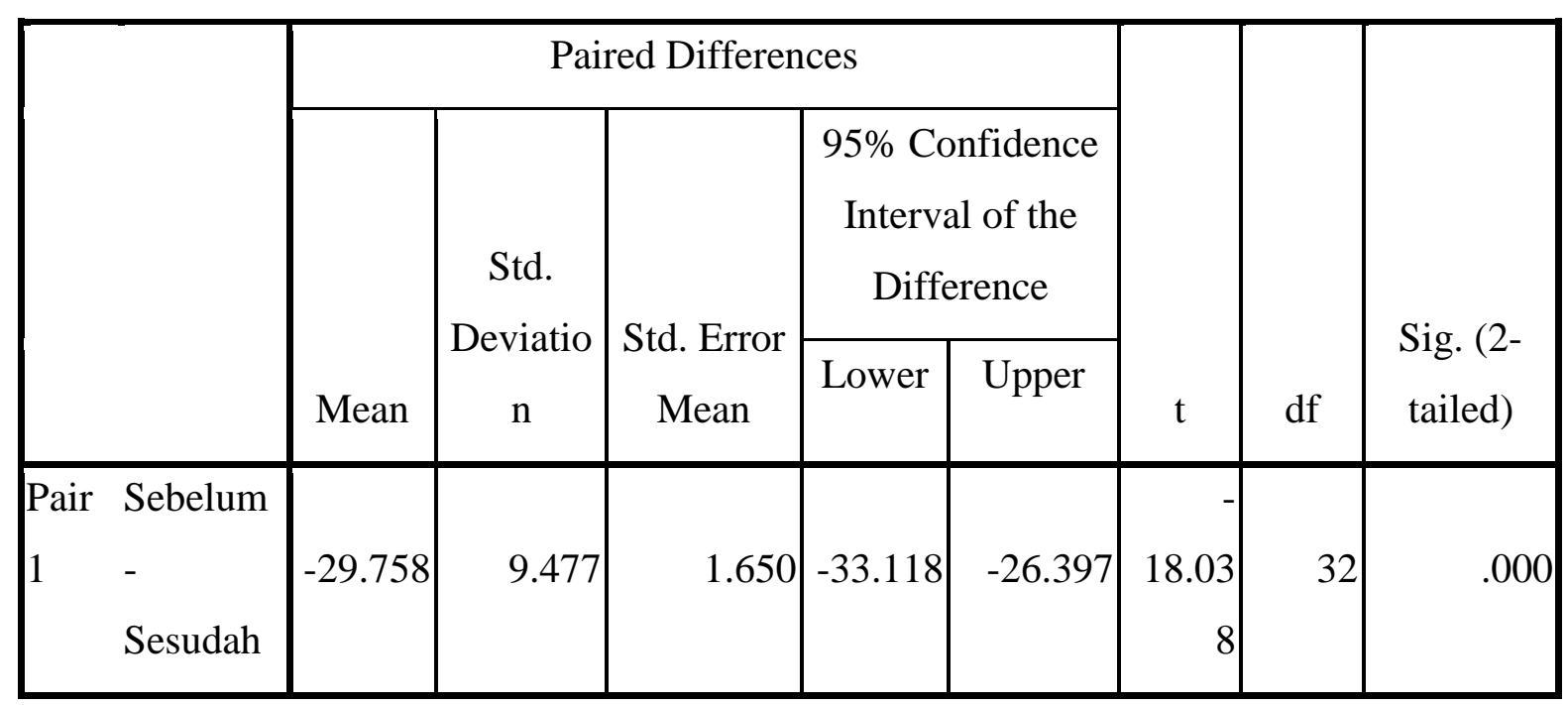

Berdasarkan tabel 4.11 diketahui nilai signifikansi motivasi adalah sebesar 0,000 dimana nilai tersebut adalah kurang dari 0,05 maka terdapat perbedaan sebelum dan sesudah pembelajaran menggunakan media presentasi prezi. Sehingga dapat disimpulkan media presentasi prezi berpengaruh terhadap motivasi belajar siswa. Apabila sudah tidak terdapat revisi, maka media presentasi prezi dapat dikemas kedalam CD (Compack Disk) agar media tersebut dapat disimpan dan mudah digunakan sebagai alat bantu guru dalam pembelajaran akuntansi di kelas. 
Pembelajaran adalah suatu konsep dari dua dimensi kegiatan (belajar dan mengajar) yang harus direncanakan dan diaktualisasikan, serta diarahkan pada pencapaian tujuan atau penguasaan sejumlah kompetensi dan indikatornya sebagai gambaran hasil belajar (Majid, 2013:5). Pembelajaran yang menyenangkan dapat diciptakan guru dengan menggunakan metode belajar yang tepat dan penggunaan media pembelajaran sebagai alat bantu pencapaian tujuan pembelajaran. Sekarang ini, saat teknologi computer dan komunikasi telah berkembang pesat, guru dituntut untuk menguasai teknologi agar dapat menciptakan pembelajaran yang menarik dengan memanfaatkan teknologi.

Hamalik dalam Arsyad (2011:23) menyatakan bahwa pemanfaatan media dalam pembelajaran dapat membangkitkan motivasi belajar siswa. Salah satu jenis media pembelajaran di kelas adalah sebagai media presentasi. Banyak media presentasi yang dapat dipakai saat ini, presentasi dengan menggunakan media pembelajaran yang inovatif akan menciptakan kegiatan pembelajaran yang lebih efektif. Media presentasi juga dapat membantu guru untuk menyampaikan materi pembelajaran agar lebih menarik. Salah satu aplikasi media presentasi alternatif yang inovatif adalah prezi.

Prezi adalah salah satu perangkat lunak pembuatan slide presentasi secara online. Berbeda dengan power point, prezi memberikan ruang yang lebih bebas untuk menuangkan kreasi dalam pembuatan slide presentasi. Media prezi lebih unggul dibandingkan dengan power point karena prezi menggunakan zooming user interface, yang memungkinkan pengguna prezi untuk memperbesar dan memperkecil tampilan presentasi. Prezi memiliki tampilan seperti mind map, sehingga lebih memudahkan siswa untuk memahami materi yang disampaikan, dengan begitu semua komponen atau media yang digunakan dalam presentasi dapat dipadukan sesuai dengan konsep (Rosadi, 2012).

Mind mapping adalah sebuah sistem berpikir yang bekerja sesuai dengan cara kerja alami otak manusia dan mampu membuka dan memanfaatkan seluruh potensi dan kapasitas otak manusia sehingga menjamin tingkat kreativitas dan kemampuan berpikir yang lebih tinggi bagi penggunaannya. Mind mapping mempunyai kegunaan yang sangat besar, terutama untuk belajar dan mengajar. Untuk keperluan belajar, mind mapping sangat bermanfaat pada saat meringkas, mencatat dan mengkaji ulang. Untuk keperluan mengajar, mind mapping bagus diterapkan pada saat guru mencatat, mempersiapkan materi pengajaran dan managemen waktu pengajaran. Penggunaan mind map untuk keperluan belajar dan mengajar akan sangat membantu proses belajar dan mengajar itu sendiri (Silaban, 2012:4).

Media presentasi prezi merupakan salah satu media berbentuk mind mapping yang dapat digunakan guru dalam kegiatan belajar mengajar di dalam kelas. Mind mapping dalam 
media prezi lebih menekankan pada kata-kata kunci yang disusun berdasarkan pengelompokan informasi. Dalam media presentasi prezi, siswa dapat berimajinasi dan lebih kreatif karena dengan tampilan mind map, alur pikiran siswa lebih terarah, terdapat warnawarna yang membantu mempermudah siswa dalam mengingat serta memberi daya tarik sehingga mudah dipelajari, dapat dibuat disertakan gambar-gambar yang menunjang konsep atau ide sehingga lebih mudah dipahami siswa.

Dalam penelitian ini, prezi digunakan sebagai media presentasi yang berperan sebagai alat bantu guru dalam penyampaian materi ajar di dalam kelas. Sebagaimana fungsi dari media pembelajaran menurut Kemp \& Dayton dalam Arsyad (20011:22) adalah untuk menyampaikan pelajaran dengan lebih menarik perhatian siswa, pembelajaran menjadi lebih interaktif, waktu pengajaran lebih singkat, proses belajar mengajar di kelas meningkat, dan peran guru dapat berubah ke arah yang lebih positif. Dengan tampilan mind map dalam media prezi dapat meningkatkan motivasi belajar siswa dan membantu guru dalam menyampaikan materi di depan kelas. Substansi dari media presentasi prezi ini adalah mempermudah siswa dalam memahami dan menunjang sumber belajar. Adanya pemanfaatan media presentasi yang praktis dan inovatif yang dikemas dalam media yang menarik dapat membangun struktur pengetahuannya berdasarkan kematangan kogntif yang dimilikinya.

Produk yang dihasilkan dari penelitian dan pengembangan ini berupa media presentasi prezi yang dapat digunakan dalam kegiatan pembelajaran akuntansi. Produk ini telah melalui proses revisi berdasarkan validasi ahli media, validasi ahli materi dan uji coba pengguna siswa dan uji coba pengguna guru. Berdasarkan data yang diperoleh dari uji paired sample T-test diketahui bahwa terdapat perbedaan motivasi belajar siswa sebelum dan sesudah pembelajaran menggunakan media presentasi prezi.

Hasil penelitian ini sejalan dengan penelitian yang telah dilakukan oleh Wulandari (2014) yang berjudul "Perbandingan Hasil Belajar Siswa Melalui Media Pembelajaran Prezi dengan Power Point pada Mata Diklat Akuntansi" yang menyatakan bahwa terdapat perbedaan hasil belajar siswa antara kelas yang diajar dengan menggunakan media prezi dan kelas yang diajar menggunakan media power point.

Hasil produk dikemas dalam bentuk CD (Compack Disk) agar software prezi dapat disimpan dan mudah digunakan. Pengoperasian media prezi menggunakan komputer, speaker dan bantuan LCD. Kelebihan dari media presentasi prezi adalah adanya zoomable canvas sehingga dapat memfokuskan slide kesetiap kalimat dengan pergerakan slide yang cukup dinamis dan variatif. Media prezi dapat menyisipkan gambar, foto ataupun video kedalam slide juga menunjang kemudahaan dalam menyusun slide presentasi yang diinginkan 
(Rosadi, 2012). Selain itu dengan menggunakan media prezi pembelajaran akuntansi menjadi lebih menarik dan menyenangkan, produk yang dihasilkan berupa media presentasi prezi yang dapat digunakan guru dalam kegiatan pembelajaran.

Disamping memiliki kelebihan, media pembelajaran berbasis prezi juga memiliki kekurangan yaitu untuk ukuran media prezi terlalu besar, penyimpanan media prezi relatif besar hingga100MB. Jika ingin mempresentasikan hasil media tanpa adanya koneksi internet (offline), pengguna harus menyimpan file terlebih dahulu dalam bentuk .rar, kemudian mengextract menjadi file prezi. Guru yang menggunakan media ini diharapkan dapat mengoperasikan komputer atau laptop.

\section{SIMPULAN}

Media presentasi prezi yang dibuat telah layak digunakan sebagai alat bantu guru dalam pembelajaran akuntansi di kelas, karena telah di uji validitasnya dan uji coba pengguna siswa dan guru. Penilaian kelayakan media prezi berdasarkan ahli media dengan rata-rata persentase $96,84 \%$, ahli materi diperoleh rata-rata $89,00 \%$, uji coba pengguna siswa diperoleh rata-rata $89,53 \%$, uji coba pengguna guru diperoleh rata-rata 86,89. Data analisis angket motivasi belajar siswa menggunakan uji Paired Sample T-test. Berdasarkan data yang diperoleh dari uji paired sample T-test nilai signifikansi motivasi adalah sebesar 0,000 $<0,05$ maka terdapat perbedaan motivasi belajar siswa sebelum dan sesudah pembelajaran menggunakan media presentasi prezi. Sehingga dapat disimpulkan media presentasi prezi berpengaruh terhadap motivasi belajar siswa.

Saran agar pemanfaatan media presentasi prezi dapat dipergunakan secara maksimal, yaitu penggunaan media presentasi prezi hendaknya tidak lepas dari pantauan dan bimbingan guru. Agar proses pembelajaran berjalan dengan lancar sebaiknya guru sudah mempelajari media presentasi ini terlebih dahulu, dalam pengoperasian media prezi disarankan terdapat alat pendukung seperti LCD dan speaker agar suara dalam video dapat terdengar jelas.

Beberapa saran pengembangan produk lebih lanjut yaitu produk dibuat hanya untuk materi tertentu yaitu siklus akuntansi perusahaan jasa, oleh karena itu disarankan kepada peneliti selanjutnya dapat membuat produk dengan pokok bahasan siklus akuntansi perusahaan dagang, keinteraktifan media dapat ditambahkan dalam media presentasi prezi yang akan dikembangkan selanjutnya, produk media presentasi prezi yang dibuat masih menggunakan kurikulum KTSP, peneliti selanjutnya diharapkan dapat mengembangkan media prezi dengan kurikulum baru yaitu Kurikulum 2013. 


\section{DAFTAR RUJUKAN}

Arsyad, Azhar. 2011. Media Pembelajaran. Jakarta: PT. Raja Grafindo Persada

Bakrowi. 2007. Microsoft Office Power Point Sebagai Media Pembelajaran Materi Unsur, Senyawa, dan Campuran Berbasis STAD. Jurnal Pendidikan Inovatif, 3-1, (online), (http://jurnaljpi.files.wordpress.com/2009/09/vol-3-no-1-bakrowi.pdf) diakses tanggal 5 Desember 2014

Budiningsih, Aris. 2012. Belajar dan Pembelajaran. Jakarta: Rineka Cipta.

Buzan, Tony. 2006. Use Your Head (Gunakan Kepala Anda) Edisi Milenium. Jakarta: Interaksara

Gall, M.D., Gall, J.P \& Borg, W. R. 1983. Educational Research. Boston: Pearson Education, Inc

Kartika, Innecke. 2011. Teori-teori Pendidikan. (online) (http://imadiklus.googlecode.com/files/TEORITEORI\%20PENDIDIKAN\%20(TEORI\%20KOGNITIF,\%20TEORI\%20PENDIDIKAN $\%$ 20HUMANISME,\%20TEORI\%20PENDIDIKAN20\%BEHAVIORISME, \%20TEORI\%20PENDIDIKAN\%20KONSTRUKTIVISME,\%20.pdf) diakses tanggal 5 Maret 2015

Kurniawan, Dwi. 2012. Metode Mind Mapping. (online) (http://ikhs.wordpress.com) diakses tanggal 31 Juli 2015

Majid, Abdul. 2013. Strategi Pembelajaran. Bandung: Remaja Rosdakarya.

Rosadi, Andrian. 2012. Media Presentasi Prezi. (online) (http://teknologi.kompasiana.com/), Diakses 5 Januari 2015.

Silaban, Ramlan. 2012. Pengaruh Media Mind Mapping Terhadap Kreativitas Dan Hasil Belajar Kimia Siswa SMA Pada Pembelajaran Menggunakan Advance Organizer. Jurnal Pendidikan Kimia, 4(2), Hal 4, (online)

(http://digilib.unimed.ac.id/public/UNIMED-Article-23269-1.\%20Ramlan-Unimed.pdf) diakses tanggal 30 Juli 2015

Sugiyono. 2009. Metodologi Penelitian Pendidikan: Pendekatan Kuantitatif, Kualitatif dan $R \& D$. Bandung: CV Alfabeta.

Supardan, Dadang. 2004. Pendekatan Konstruktivisme dalam Pembelajaran SosiologiAntropologi Di Sekolah/Madrasah. (online) (http://file.upi.edu/Direktori/FPIPS/JUR._PEND._SEJARAH/195704081984031) diakses tanggal 5 Maret 2015

Thobroni, Muh. \& Mustofa. 2011. Belajar dan Pembelajaran: Pengembangan Wacana dan Praktik Pembelajaran dalam Pembangunan Nasional. Jogjakarta: Ar-Ruzz Media.

Utari, Yani Putri. 2014. Pengembangan Media Pembelajaran Fisika Online Prezi dalam Pokok Bahasan Alat Optik pada Siswa Kelas X IPA SMA Negeri 3 Purworejo Tahun Pelajaran 2013/2014. Radiasi, 5(2), Hal: 45,(online) (http://ejournal.umpwr.ac.id/index.php/radiasi/article/view/1708), Diakses 19 Desember 2014

Windura, S. 2008. Mind Map For Business Effectiveness. Jakarta: Gramedia.

Wulandari, Novita Ayu dan Hakim, Luqman. 2014. Perbandingan Hasil Belajar Siswa Melalui Media Pembelajaran Prezi dengan Power Point pada Mata Diklat Akuntansi. (online), (http://ejurnal.unesa.ac.id/mobile/?sess=1ec47bc8b5e270348a7c288bf5ab4f2) Diakses tanggal 30 November 2014

Yoga, Djohan. 2007. Kegiatan Belajar Mengajar Berbasis Mind Map. (online), (http://www.paxhigh.com/doc/applied_rt-mm.pdf) diakses tanggal 30 Juli 2015 
